\title{
A POSTFOUNDATIONALIST RESEARCH PARADIGM OF PRACTICAL THEOLOGY
}

\author{
Author: \\ Sung Kyu Park ${ }^{1,2}$ \\ Affiliations: \\ ${ }^{1}$ Biblical and Theological \\ Studies, Nairobi \\ International School of \\ Theology, Kenya \\ ${ }^{2}$ Department of Practical \\ Theology, University of \\ Pretoria, South Africa \\ Correspondence to: \\ Sung Kyu Park \\ email:
}

sungpark215@yahoo.com

Postal address:

PO Box 1049 Village

Market, Nairobi 00621,

Kenya

Keywords:

Postfoundationalism;

practical theology;

narrative; social

constructionism

Dates:

Received: 03 May 2010

Accepted: 18 July 2010

Published: 20 Oct. 2010

How to cite this article:

Park, S-K., 2010, 'A

postfoundationalist

research paradigm of

practical theology',

HTS Teologiese Studies/

Theological Studies 66(2),

Art. \#849, 6 pages. DOI:

10.4102/hts.v66i2.849

This article is available at:

http://www.hts.org.za

\section{Note:}

Sung Kyu Park is the director/founder of Nakuru Pastoral Leadership Training Centre, a pastoral leadership training institute in Kenya. He also teaches at the Nairobi International School of Theology (NIST). This article is adapted from his PhD dissertation, submitted to the Department of Practical Theology, University of Pretoria, under the supervision of Prof. Julian C. Müller.

(C) 2010. The Authors. Licensee: OpenJournals Publishing. This work is licensed under the Creative Commons Attribution License.

\section{ABSTRACT}

Practical theology describes a context, interprets what has been discovered, brings in Christian norms, and constructs models of Christian practice. It is a process that involves epistemology and hermeneutics. For practical theology to be transformative, a postfoundational theological framework that allows interdisciplinary work and interpretation of experience in a given context is essential. Research in postfoundational practical theology can be conducted using narratives and social constructionism to obtain meaning from events or situations and to construct preferred realities.

This article examines and argues for postfoundationalism - transversal reason, interdisciplinarity and interpreted experience - as a viable theological option against rigid foundationalism and relativistic nonfoundationalism. Also discussed are the process and the interdisciplinary nature of practical theology. It is suggested that narrative research and social constructionism should be part of the research paradigm of postfoundational practical theology.

\section{POSTFOUNDATIONALISM}

In practical theological research, a postfoundationalist approach over against rigid foundationalism and relativistic nonfoundationalism is vital for meaningful theological inquiry.

\section{Foundationalism and nonfoundationalism}

Epistemologically, foundationalism at all times implies the holding of a position in an inflexible and infallible manner; invoking ultimate foundations on which to construct the evidential support system of various convictional beliefs. Foundationalism is the 'thesis that all our beliefs can be justified by appealing to some item of knowledge that is self-evident or indubitable' (Van Huyssteen 1997:2-3). Schrag (2006:21) states, 'Foundationalism finds its mission in a quest for certainty. Unimpeachable knowledgeclaims is what it is after'. These foundational systems of knowledge are called 'first principles' (Thiel 1994:2) or 'aristocratic beliefs' (Rescher 1992:161), which are intrinsically credible. Such basic givens can be anything from sense data to universals, essences, and experiences, including religious experiences. Philosophically, the foundationalist views transform the narratives by which we live into the typical grand metanarratives of modernity (Van Huyssteen 1999:62). Lyotard (1984:18) refers to this as 'grand narratives' or 'master narratives'. In the natural sciences, the implication of foundationalism gave rise to a positivist empiricism or scientific materialism that, per definition, renders all religion, theology and theological reflection subjective and meaningless (Barbour 1990:4). Theologically, foundationalism implies biblical literalism, or positivism of revelation, which isolates theology from other reasoning sciences in that it denies the crucial role of interpreted religious experience in all theological reflections (Van Huyssteen 1999:62-63), thereby leaving the theologian to speak a language that may be internally coherent but powerless to communicate its content because it is cut off from all nontheological discourses (Green 1989:34).

Nonfoundationalists, on the other hand, reject the traditional rationalist or empiricist definition of truth as an isolated correspondence between the self and the world, as well as the concept that sense experience or ideas are privileged as the authoritative basis of human knowing (Thiel 1994:10). They 'offer a picture of human knowledge as an evolving social phenomenon shaped by the practical implications of ideas within a larger web of beliefs' (Van Huyssteen 1999:64). Thus, meaning is never fixed objectively or apprehended in context-free theories, but is always local or contextual (Quine 1969:27). Nonfoundationalism also denies any alleged strong foundations for belief systems, and argues that all our beliefs form a groundless web of interrelated beliefs. Nonfoundationalists emphasise the crucial epistemic importance of community, that every community and context has its own rationality. Nonfoundationalism or anti-foundationalism is one of the most important roots or resources of postmodernism (Cahoone 1995:13). The term 'postmodern condition', which was coined by Lyotard (1984:xxiv), was used to reveal the incredulity of all metanarratives of modernity. We find the most significant postmodern challenge to epistemological foundationalism in Rorty's neopragmatism (Van Huyssteen 1999:64-65). For Rorty (1989:22) our language, conscience and community are the products of time and chance, and the justification of any claims to knowledge is a matter of social practice only. Like Rorty (1982:xli-xliii), Joseph Rouse views natural science as social practice, as well. Thus, science is no longer viewed as the paradigm of rationality, but as one genre of literature. In this kind of postmodern culture, religious inquiry can coexist peacefully with scientific and all other forms of inquiry, since there would be no need to find metanarratives or an encompassing theory of rationality. This nonfoundationalist claim, that no authoritative givenness exists, is incompatible with theological claims of reasoned attempts to understand the authoritative givenness of God's revelation in the Scripture, or its interpretation in sanctioned religious traditions. Van Huyssteen (1999:69) asks, 'Is there a positive and constructive way of appropriating postmodern nonfoundationalist critique for theology without succumbing to the epistemic hazards of nonfoundationalism?' 


\section{Postfoundationalism}

Having found both foundationalism and nonfoundationalism inadequate for theological discourse, Van Huyssteen (1999:113) proposes a postfoundational theology that fully acknowledges the role of context, the epistemically crucial role of interpreted experience, and the role of tradition in shaping religious values. Theological reflection in postfoundationalism also points creatively beyond the confines of the local community or culture toward a plausible form of cross-contextual and interdisciplinary conversation. Over against the alleged objectivism of foundationalism and the extreme relativism of most forms of nonfoundationalism, postfoundationalism emerges as a viable third option that allows cross-disciplinary conversations with our beliefs intact, and the shared resources of human rationality in different modes of reflection. Müller (2004:4) calls this 'a third way', a way out of the 'stuckness' of modernistic or foundationalist science and theology, on the one hand, and the fatalism of some post-modernistic approaches, on the other. A postfoundational space is created between modernity and postmodernity as we reconsider postmodernity's farewell to reason, the disparagement of logos, and the celebration of difference, plurality and multiplicity (Schrag 1992:8).

\section{Rationality}

Rationality in postfoundationalism is 'an awareness of the shared cognitive, pragmatic, and evaluative dimensions' (Van Huyssteen 1999:239). It is able to give an account and provide a rationale for the way one thinks, chooses, acts and believes (Van Huyssteen 1997:39). This rationality describes the dynamic interaction of our various disciplinary dialogues with one another - as a form of transversal reasoning that justifies and urges an acknowledgment of multiple patterns of interpretation as one moves across the borders and boundaries of different disciplines (Van Huyssteen 2000:427). Through transversal reasoning, this rationality provides a common ground for communication between people who have different beliefs and cultures.

Transversal reasoning, as mentioned above, originated from and was used by Shrag (1992:149) to describe the way in which reason exists at the point of intersection between various disciplines, paradigms and social practices. Shrag (2006) continues,

Transversality enables one to unify without appeals to overarching universals and undergirding necessary conditions, neither of which are receptive to temporal passage and changing conditions, be it the successive moments of consciousness or the changing scenes of social practices.

(Schrag 2006:28)

This transversal reasoning was also called 'shared rational resources' or 'the resources of human rationality' by Van Huyssteen (2006:12, 40), and 'universal intent' by Nicholas Rescher (1992:11). For Van Huyssteen (2006:11-13), rationality takes many different forms, allowing us to integrate our multi-faceted lives; understand ourselves as individuals and communities; and relate to one another within and across complex socio-cultural structures. It is the most important 'epistemic goal' in shaping the way in which we interact with others.

Postfoundational rationality is based on our own experience, but is capable of reaching beyond. It starts with an individual and extends to community. It acknowledges personal commitments; identifies the shared resources of rationality in different reasoning strategies; and reaches beyond the boundaries of our own epistemic communities in cross-disciplinary conversation. This rationality differs from community to community; there is no trans-cultural rationality. Therefore, postfoundational rationality is context-specific and embedded in tradition. At the heart of the nature of rationality, there is a never-ending quest for intelligibility - a quest for optimal understanding - that is expressed in our ability to solve problems through an ongoing process of personal judgment and intersubjective accountability (Van Huyssteen 1999:173-174; 2006:11).

Van Huyssteen (1999:267) also differentiates theological rationality from scientific rationality, stating that 'There are no universal standards of rationality against which we can measure other beliefs or competing research traditions'. Rationality should never be reduced to scientific rationality, and scientific rationality should never be reduced to natural scientific rationality. Furthermore, scientific rationality is different and should be treated differently to theological rationality because of a different object, language and method (Van Huyssteen 1997:263-265, 1999:129). However, these different reasoning strategies in intellectual inquiry do not mean that they do not share the same resources of human rationality, overlapping epistemic goals and similar interpretative procedures. The practical embeddedness of rationality in social, historical, and cultural contexts justifies its interdisciplinary claims to epistemological adequacy (Van Huyssteen 1999:119, 130). Rationality is alive in the concrete world of human thought, discourse and action, whether it is sought in the domains of science, philosophy or theology (Schrag 2006:29).

\section{Interpreted experience}

In postfoundational theology, the focus will be the relentless questioning of uncritically held crypto-foundational assumptions. It engages in critical theological reflection in order to evaluate the roles of experience, tradition and the classic Biblical text. We explore our beliefs experientially and interpretatively. It allows the creative fusion of hermeneutics and epistemology. A postfoundationalist theology, therefore, acknowledges context and the epistemically crucial role of interpreted experience (Van Huyssteen 1997:4). Just as all scientific observations are theory-laden, so all religious experiences are interpretation-laden. This interpretation provides valid religious meaning (Van Huyssteen 1997:19-20). Agreeing with Van Huyssteen, Schrag (2006:25) asserts that interpretation is called upon both in scientific discovery and humanistic inquiry. It cuts across the culture spheres of science, morality, art, and religion'.

This interpreted experience starts from the individual's experience and proceeds towards the interpersonal and social (Müller 2004:7). Don Browning (1996:61), presenting a similar picture in his A fundamental practical theology, proposes differentiating common human experiences into three poles or foci, (1) interpretations of the practices, inner motivations and socio-cultural history of individual agents, (2) interpretations of relevant institutional patterns and practices and (3) interpretations of the cultural and religious symbols that give meaning to individual and institutional action. These three poles of interpretation make up a model developed from James and Evelyn Whitehead's (1980) two poles of reflection, that is, 'personal' and 'corporate' experience, which is based on David Tracy's (1975:43) 'common human experience'. Tracy critically correlates two principal sources of theology, (1) Christian texts and (2) common human experience and language.

Van Huyssteen calls this interpretation a 'received interpretation', in the sense that it is socially constructed, as opposed to an individual or subjective construction, and emphasises the contribution of tradition, culture and cultural discourses to the interpretation (Müller 2004:7). Josiah Royce's idea that interpretation always proceeds within a community, and Charles Peire's argument that reality can never be known adequately by an individual, share the same social constructionist idea (Browning 1996:50-51). Van Huyssteen's (1997:16) argument encapsulates it well: 'Our search for legitimate knowledge always takes place within the social context of a community...'. 


\section{Interdisciplinary conversation}

A third major strength of postfoundationalism lies in interdisciplinary possibilities. A postfoundationalist notion of rationality in theological reflection claims to point beyond the confines of the local community or culture towards interdisciplinary conversation (Van Huyssteen 1997:4). Van Huyssteen argues, in particular, for interdisciplinary dialogue between theology and science, although the domains of rationality of these two disciplines are different. For interdisciplinary dialogue between disciplines, paradigms and practices to occur, transversal reason, as mentioned above, is employed. Van Huyssteen (2006) writes:

Interdisciplinary discourse, then, is an attempt to bring together disciplines or reasoning strategies that may have widely different points of reference, different epistemological foci, and different experiential resources. This 'fitting together,' however, is a complex, multileveled transversal process that takes place not within the confines of any given discipline...but within the transversal spaces between disciplines.

(Van Huyssteen 2006:9)

Interdisciplinarity is further supported by the following arguments. Philip Clayton (1989:3-5), proposing three types of religious explanations - private, communal and transcommunal - defines transcommunal explanation as an intersubjective explanation that transcends the boundaries of the individual or the religious community. Gelwick (1983:422) states, 'Interdisciplinary study itself is a paradigm shift'; for an interdisciplinary conversation to occur, epistemic humility is required and the willingness to learn is primary. Don Browning (1996:81) also stresses the importance of interdisciplinary dialogue by saying, 'It is extremely important for theology especially practical theology - to have a strong and positive relation with the modern human sciences'.

As we have seen above, the creative fusion of hermeneutics and epistemology in postfoundational critical theological reflection occurs through the processes of interpreted experience, use of rationality and transversal reason, and interdisciplinary conversation. All of these elements of postfoundationalism are critical to a practical theological process.

\section{PRACTICAL THEOLOGY}

The term practical theology originally emerged in the German Protestant tradition as part of the academic theological curriculum in the late eighteenth century (Pattison \& Woodward 2000b:2). While there are many definitions of practical theology, my purpose is not to elaborate on those varying definitions, but instead to provide some significant characteristics of practical theology, which are (1) transformational, (2) contextual and situationally related, (3) experiential, (4) interrogative, (5) interdisciplinary, (6) analytical and constructive and (7) dialectical and disciplined (Pattison \& Woodward 2000b:6).

Traditionally, theology started from the text and the text provided the norms of practice. Practical theology, therefore, has been treated as an inferior form of theology. However the whole theological process should be practical from the beginning, because theology that is irrelevant to life in its abstract forms is not meaningful. Theology starts with the concrete and ends with the concrete. Browning's (1996:7) view makes sense when he says that theology begins in present theory-laden practice and develops through a retrieval of normative theory-laden practice to the creation of more critically held theory-laden practices.

\section{Practical theological process}

Practical theology engages in reflective, critical, communicative, interpretive, hermeneutical and correlational dialogue in order to achieve its purpose of bringing new meanings and horizons to specific contexts. Browning (1996), in his A fundamental practical theology, proposes 'descriptive', 'historical' and 'systematic', and 'strategic practical theology' as a theological process. Descriptive theology is a hermeneutical task. It starts with a whole, goes to interpretive critical thinking, and then reconstructs. It describes a question in all its situated richness. It describes how people think and act practically in specific contexts. Therefore, descriptive theology aims for a 'thick' description of situations. Practical theology, then, moves from descriptive theology and its formation of questions back to historical theology, and asks the following question, 'What do the normative texts that are already part of our effective history really imply for our praxis as honestly as possible?' (Browning 1996:49). It is to assist in understanding what the text and the tradition say to the present context. The following statement by Browning (1996) succinctly summarises what happens in this stage of practical theology:

This is where the traditional disciplines of biblical studies, church history and the history of Christian thought are located. In this scheme, these disciplines and all their technical literary-historical, textual and social scientific explanatory interests are understood as parts of a larger practical hermeneutical enterprise. Their technical, explanatory and distancing manoeuvres are temporary procedures designed to gain clarity within a larger hermeneutic effort to understand our praxis and the theory behind it.

(Browning 1996:49)

As historical theology is engaged in dialogue, however, it is not an individual matter, but a communal interpretive process, especially in regards to both the theological academy and congregations. Then, systematic theology, the third movement, becomes engaged. It is, according to Gadamer's hermeneutics, a fusion of horizons between the vision implicit in contemporary practices and the vision implied in the practices of the normative Christian text. Systematic theology endeavours to gain as comprehensive a view of the present as possible and examine large, encompassing themes of our present practices. The first three sub-movements of practical theology - descriptive, historical and systematic - have prepared us for the last movement, that is, strategic practical theology. The new praxis and norms put forth in strategic practical theology, which are based on the new horizon created in systematic theology, are truly powerful sources of transformation. Unless practical theology aims at and brings about transformation of some sort for the betterment of Christian praxis, the whole hermeneutics and epistemology of practical theology becomes an academic and theoretical activity (Browning 1996:51, 279).

David Tracy's (1983:76) practical theology shares the same line of thought concerning interaction between theory and practice and their critical correlation: 'Practical theology is the mutually critical correlation of the interpreted theory and praxis of the Christian fact and the interpreted theory and praxis of the contemporary situation'. Osmer (2006:328-330) proposes four interrelated forms of research: 'descriptiveempirical', 'interpretive', 'normative' and 'pragmatic'. In this model, descriptive-empirical research firstly investigates what is happening in a particular field of social action. Secondly, the practical theologian interprets what has been discovered. Thirdly, the normative process offers the theologian guidance that is explicitly theological, drawn from the sources of Christian truth such as Scripture, tradition, experience and reason. The final, pragmatic process constructs models of Christian practice and 'rules of art'. Here, the practical theologian seeks to suggest guidance to individuals and communities about how they could carry out certain practices.

It should be noted that other practical theologians use a similar methodology. Lartey's (2000:128-134) 'pastoral cycle' presents a model similar to Browning's argument concerning 'fundamental practical theology'. In presenting several different approaches to practical theology, Lartey promotes his pastoral cycle, which consists of experience; situational analysis; theological analysis; situational analysis of theology; and response. This model of practical theology introduces a process and there are interactions 
between situational analysis and theological analysis, and also between theological analysis and situational analysis of theology. Pattison and Woodward's (2000a:36-50) 'conversation model' of pastoral theology also has such characteristics of practical theology as we are dealing with here - dialectical, interdisciplinary, reflection-based and experiential-practical.

\section{Interdisciplinarity in practical theology}

In the twentieth century, practical theologians engaged the human sciences in their work. Three different approaches of practical theology to interdisciplinary work can be identified, (1) the correlational approach of Paul Tillich and the revised correlational approaches of David Tracy and Don Browning, (2) the more recent transformational approach of James Loder and Deborah van Deusen Hunsinger and (3) the transversal approach of Van Huyssteen. Firstly, the correlational approach 'views theology as standing in a mutually influential relationship to the intellectual resources and/or emancipator praxis of culture' (Osmer 2006:339). From this perspective, a phronetic social science may provide important clues about its role in contemporary life for practical theology. Secondly, Van Deusen Hunsinger's (1995) transformational approach requires the practical theologian to allow the social sciences to have their say about social reality while retaining the distinctive language and disciplinary perspective of theology. In this approach, integration between theology and social science occurs in the person of the practical theologian, not at a systematic disciplinary level, as different fields of social science bear on particular problems or situations. Thirdly, Van Huyssteen's transversal approach also argues that interdisciplinarity must remain person- and perspectivespecific in light of the pluralism of today. Instead of generalised statements about the relationship between theology and social science, concrete accounts of their relationship and interactions are preferred (Osmer 2006:338-341). Osmer (2006:341) argues that the correlational approach reflects modern views of culture, while the transversal approach reflects postmodern views.

\section{NARRATIVE AND SOCIAL CONSTRUCTIONISM}

Narrative is one of the main characteristics of postmodernity, following Wittgenstein's (1961:115) 'The limits of my language mean the limits of my world'. However, Van Huyssteen (1999:177) claims: 'In a postfoundationalist notion of rationality, the narrative quality of one's own experience...is always going to be rationally compelling'. An awareness of the role of narrative in constructing human experience and giving significance to events in our lives has only recently surfaced in the human sciences, and narrative theory of human understanding focuses its attention on existence as it is lived, experienced and interpreted by the human person. Furthermore, this narrative construction of human experience is socially derived (Polkinghorne 1988:106, 125, 184). Therefore, narrative research and social constructionism are in line with postfoundational ideas of rationality. Furthermore, this narrative approach is a valid form of doing theology in Africa, since Africans experience life through stories.

\section{Narrative}

We understand and live our lives through stories. The stories that circulate in society constitute our lives, and our daily experiences also influence the stories that circulate in society. According to Polkinghorne (1988:137-146), the concept of narrative action was born as an alternative to the following three positions, (1) the means-end rationality of Max Weber, that is, purposeful action is the result of a means-end calculation to achieve personal ends, (2) structuralism, that is, action is the enactment of transcendent and logically ordered rules and (3) action as language game, that is, action is behaviour conforming to socially agreed-upon rules. When action is understood within the systems mentioned above, the richness and fullness of its meaning disappear. Against the aforementioned approaches to human actions, the concept of human action proposed by a narrative approach is that action is an expression of existence, and that its organisation manifests the narrative organisation of human experience. This hermeneutically based understanding of human behaviour as a narrative expression of existence can produce far more authentic and useful descriptions for a science of the human realm.

Paul Ricoeur's (1983:ix) claim concerning history as a narrative form, in that narrative throws light on the nature of human existence, and Freud's theory (Schafer 1983:240) that makes narratives a preferred form of explanation of events, tells of the importance of narrative in our lives. In the research arena, the narrative approach is a new form of research pattern. According to Müller (1999:1), the 'narrative approach has made the discovery that people do not tell stories only for interest's sake or for entertainment but that life's grain is exposed through these stories'. One foundational understanding of narrative research is that we view people not as 'research subjects', but as 'research participants' or 'co-researchers' (Müller, Van Deventer \& Human 2001:77). In other words, research is not conducted on them, but with them. There are two kinds of narrative research. One is descriptive and aims at rendering the narrative accounts already in place as the means for ordering and making temporal events meaningful. The criterion for evaluating this kind of narrative research is the accuracy of the researcher's description in relationship to the operating narrative scheme. The other kind is explanatory, and it aims at constructing a narrative account that explains 'why' a situation or event involving human actions has happened (Polkinghorne 1988:161). In narrative research, narratives are also understood to create an alternative story or understanding, and questions are asked not to gather information, but to generate experience (Freedman \& Combs 1996:113).

In narrative research, research participants are valued and the researcher is involved in the lives of research participants. In the empiricist tradition, the investigator who 'discovers' or 'reveals' the true nature of things is honoured. As a result, the investigator's voice is dominant and other voices are suppressed. In narrative research as an alternative, researchers seek to admit more voices to the conversation, which generates understanding through the first-hand accounts (Gergen 1999:95). The researcher therefore strives for participatory interaction in the narrative approach, and a story develops through the active interaction between the researcher and participants (Müller et al. 2001:85). Mishler (1986:248-249) comments on the control of the research context by the researcher, 'If we wish to hear respondents' stories, then we must invite them into our work as collaborators, sharing control with them, so that together we try to understand what their stories are about'. This context is different from the typical survey interview context, in which the interviewer controls the interview by asking specific questions and intervenes when the answers are 'off-track' (Polkinghorne 1988:161) or 'suppresses narrative accounts in interviews' (Mishler 1986:248).

The following comment about narratives by Polkinghorne (1988) summarises the central place of narrative in our lives.

Our lives are ceaselessly intertwined with narrative, with the stories that we tell and hear told, with the stories that we dream or imagine or would like to tell. All these stories are reworked in that story of our own lives which we narrate to ourselves in an episodic, sometimes semiconscious, virtually in interrupted monologue. We live immersed in narrative, recounting and reassessing the meanings of our past actions, anticipating the outcomes of our future projects, situating ourselves at the intersection of several stories not yet completed.

(Polkinghorne 1988:160)

\section{Social constructionism}

'The construction of meaning is ubiquitous; it plays a role in all that 
humans do and think' (Clayton 2006:95). Archbishop Desmond Tutu is reported as once having stated:

[A] person is not basically an independent, solitary entity. A person is human precisely in being enveloped in the community of other human beings, in being caught up in the bundle of life. To be is to participate.

(Krog 1998:143)

In an increasingly diverse world, where various realities clash and traditional values are waning, social constructionism, as a postmodern project, is seen as an alternative to modernist faith in the individual mind, rationality, objectivity and truth. This is a shift from focusing on the process by which an individual person constructs a model of reality from his or her individual experience, towards focusing on the way in which people interact with one another to construct, modify and maintain what their society holds to be true, real and meaningful. This social epistemology attracts us to social constructionism (Freedman \& Combs 1996:27).

The basic tenet of social constructionism is that people construct realities together. Freedman (1996) says:

The main premise is that the beliefs, values, institutions, customs, labels, laws, divisions of labour, and the like that make up our social realities are constructed by the members of a culture as they interact with one another from generation to generation and day to day. That is, societies construct the 'lenses' through which their members interpret the world.

(Freedman 1996:16)

Without commitment to fundamental values, social constructionism is relativistic - meaning that all positions possess legitimacy in their own terms - but it is not relativism. Social constructionism invites a posture of continuing reflection; each moment of reflection is value-saturated. Commitments are situated within culture and history (Gergen 1999:231-235). Social constructionism is an alternative to scientism and humanism. Scientists argue that there are no principled differences between humans and machines, whereas humanists declare that there are many. Social constructionism offers an alternative to both traditions. Gergen (1999:214) argues that we need not decide between the two any more than we have to decide whether opera is any more true than jazz. We need to generate new conceptions that open up new alternatives for action. The point is not to search for what is fundamentally true or real, but to add to the cultural resources for relating. Berger (1967:21) writes, 'Society is the guardian of social order and meaning, not only objectively, in its institutional structures, but subjectively as well, in its structuring of individual consciousness.'

Paré (1995:3-4) discusses the locus of knowledge in the family therapy context from which epistemology has evolved, thus, (1) knowable reality - its elements and workings can be accurately and replicably discovered, described and used by human beings toward, (2) perspectivist position - reality tells us a lot about the person doing the describing, but not much about external reality and gradually to (3) a locus of knowledge in a community of persons - the realties we inhabit are those we negotiate with one another. Paré asserts that there has been a gradual, and yet incomplete, evolution from the first to the third views over the course of this century. This trend is postmodern and social constructionistic and celebrates relationship as opposed to the individual; connection over isolation; and communion over antagonism (Gergen 1999:122). Heshusius (1994:16) calls this 'participatory consciousness' as opposed to the 'alienated consciousness' of the natural sciences. Alienated consciousness requires that the act of knowing takes place through the distancing of oneself and the regulating of that distance in order to come to the known. Participatory consciousness takes place when the boundaries between the self and the other are overcome through a deep connection.

Philip Clayton (2006:91) writes about eight different levels of meaning, (1) raw data from the world and other humans, (2) the individual's project of making sense of her experience, (3) a meaningful event or moment, (4) a significant group, practice, institution, period of life, (5) a sense of meaningfulness derived from one's social world, (6) integrating multiple social or cultural worlds, (7) integrating these worlds with the world of nature and (8) making sense of existence as a whole. He rhetorically writes, 'We like to think of our religious beliefs as directly reflecting rational reflection on the world and/or the self-revelation of God, rather than as the product of social construction' (Clayton 2006:95). In the social constructionist view, the experience of self exists in the social realm (Weingarten 1991:289). The meanings of words are social constructions, meaning that words are not derived from private ideas in the mind but from social practice. The psychological is fashioned from the social. Even in education, truth does not exist beyond community. What is true or rational is an outgrowth of communal relations, and people use stories to build new visions for the future (Gergen 1999:129, 180).

In social constructionism, reason also has a different interpretation. From the early Enlightenment philosophy to its emanation in twentieth century modernism, a strong faith has been placed in the power of reason. It is the power of human reason that stands against religious and political totalitarianism and from which we derive ethical foundations. However, for constructionists, rationality is not an inner state of mind but a form of public performance - in language, symbols and material arrangements. 'Good reason' derives its intelligibility and power from relationships. Reason is lodged within a particular culture and is committed to particular values and ways of life (Gergen 1999:229). The social construction process takes us forward with new or alternative understandings. Malony (1983) states the following about the importance of dialogue for transformation:

Truth exists in the interaction 'between' persons rather than inside them....[T]ruth is discovered in the dialogue persons have with one another and that change comes through group action rather than individual insight.

(Malony 1983:189)

\section{CONCLUSION}

Van Huyssteen (1999:69) asks the question, 'Is there a positive and constructive way of appropriating postmodern nonfoundationalist critique for theology without succumbing to the epistemic hazards of nonfoundationalism?' The answer is found in his argument for the postfoundational notion of rationality, which includes transversal reason, interdisciplinarity, interpretation of experience and contextuality. Practical theology, which employs social science for 'thick' description while maintaining Christian norms intact, feels comfortable within the postfoundational theological and philosophical frame. Narrative understanding of human experience and social construction of reality can also find their place in postfoundational practical theological research when they are used properly in the process of theological inquiry.

\section{REFERENCES}

Barbour, I.G., 1990, Religion in an age of science, Harper \& Row, San Francisco.

Berger, P.L., 1967, The sacred canopy, Doubleday, Garden City, NY.

Browning, D.S., [1991] 1996, A fundamental practical theology, Fortress, Minneapolis.

Cahoone, L., 1995, The end of philosophy, SUNY Press, Albany.

Clayton, P., 1989, Explanation from physics to theology: An essay in rationality and religion, Yale University Press, New Haven.

Clayton, P., 2006, 'Religion and social sciences: Reflections on the human quest for meaning', in F.L. Shults (ed.), The 
evolution of rationality, pp. 87-106, Eerdmans, Grand Rapids, MI.

Freedman, J. \& Combs, G., 1996, Narrative therapy: The social construction of preferred realities, W.W. Norton \& Company.

Gelwick, R., 1983, 'Truly interdisciplinary study and "commitment in relativism"', Soundings 66, $422-436$.

Gergen, K.J., 1999, An Invitation to social construction, Sage, London.

Green, G., 1989, Imagining God: Theology, and the religious imagination, Harper \& Row, San Francisco.

Heshusius, L., 1994, 'Freeing ourselves from objectivity: Managing subjectivity or turning towards a participatory consciousness?', Educational Research 23(3), 15-22.

Krog, A., 1998, Country of my skull, Random House, Johannesburg.

Lartey, E., 2000, 'Practical theology as a theological form', in J. Woodward \& S. Pattison (eds.), The Blackwell reader in pastoral and practical theology, pp. 128-134, Blackwell Publishing, Malden, MA.

Lyotard, J.-F., 1984, The postmodern condition: A report on knowledge, Manchester University Press, Manchester.

Malony, H.N., 1983, 'A framework for understanding and helping the church: Organization development', in C.S. Dudley (ed.), Building effective ministry: Theory and practice in the local church, pp. 175-191, Harper \& Row, San Francisco.

Mishler, E.G., 1986, 'The analysis of interview-narratives', in T.R. Sarbin (ed.), Narrative psychology: The storied nature of human conduct, pp. 233-255, Praeger, New York.

Müller, J., 1999, Companions on the journey, Logos Electronic Publishers, Johannesburg.

Müller, J., 2004, 'HIV/AIDS, Narrative practical theology, and postfoundationalism: The emergence of a new story', unpublished article.

Müller, J., Van Deventer, W. \& Human, L., 2001, 'Fiction writing as metaphor for research: A narrative approach', Practical Theology in South Africa 16, 76-96.

Osmer, R.R., 2006, 'Toward a transversal model of interdisciplinary thinking in practical theology', in F.L. Shults (ed.), The evolution of rationality, pp. 327-345, Eerdmans, Grand Rapids, MI.

Paré, D.A., 1995, 'Family and other cultures: The shifting paradigm of family therapy', Family Process 34, 1-19.

Pattison, S. \& Woodward, J., 2000a, 'A vision of pastoral theology: In search of words that resurrect the dead (1994)', in D. Willows \& J. Swinton (eds.), Spiritual dimensions of pastoral care: Practical theology in a multidisciplinary context, pp. 36-50, Jessica Kingsley Publishers, London.

Pattison, S. \& Woodward, J., 2000b, 'An Introduction to pastoral and practical theology', in J. Woodward \& S. Pattison (eds.), The blackwell reader in pastoral and practical theology, pp. 1-19, Blackwell Publishing, Malden, MA.

Polkinghorne, D.E., 1988, Narrative knowing and the human sciences, State University of New York Press, Albany.
Quine, W. Van Orman, 1969, Ontological relativity and other essays, Columbia University Press, New York.

Rescher, N., 1992, A system of pragmatic idealism, vol. 1, Princeton University Press, Princeton.

Ricoeur, P., 1983, Time and narrative 1, transl. K. McLaughlin \& D. Pellauer, University of Chicago Press, Chicago.

Rorty, R., 1982, Consequences of pragmatism: Essays 1972-1980, University of Minnesota Press, Minneapolis.

Rorty, R., 1989, Contingency, irony, and solidarity, Cambridge University Press, Cambridge.

Schafer, R., 1983, The analytic attitude, Basic Books, New York.

Schrag, C.O., 1992, The resources of rationality: A response to the postmodern challenge, Indiana University Press, Bloomington.

Schrag, C.O., 2006, 'Traces of rationality: Acknowledgment, recognition, and repetition', in F.L. Shults (ed.), The evolution of rationality, pp. 19-29, Eerdmans, Grand Rapids, MI.

Shults, F.L. (ed.), 2006, The evolution of rationality: Interdisciplinary essays in honor of J. Wentzel van Huyssteen, Eerdmans, Grand Rapids, MI.

Thiel, J.E., 1994, Nonfoundationalism, Fortress Press, Minneapolis.

Tracy, D., 1975, Blessed rage for order, Seabury Press, Minneapolis.

Tracy, D., 1983, 'The foundations of practical theology', in D.S. Browning (ed.), Practical theology: The emerging field in theology, church, and world, pp. 61-82, Harper \& Row, San Francisco.

Van Deusen Hunsinger, D., 1995, Theology and pastoral counselling, Eerdmans, Grand Rapids, MI.

Van Huyssteen, J.W., 1997, Essays in postfoundationalist theology, Eerdmans, Grand Rapids, MI.

Van Huyssteen, J.W., 1999, The shaping of rationality: Toward interdisciplinarity in theology and science, Eerdmans, Grand Rapids, MI.

Van Huyssteen, J.W., 2000, 'Postfoundationalism and interdisciplinarity: A response to Jerome Stone', Zygon 35, 427-439.

Van Huyssteen, J.W., 2006, Alone in the world?, Eerdmans, Grand Rapids, MI.

Weingarten, K., 1991, 'The discourses of intimacy: Adding a social constructionist and feminist view', Family Process 30, 285-305.

Whitehead, J. \& Whitehead, E., 1980, Method in ministry, Seabury Press, New York.

Wittgenstein, L., 1961, Tractatus logico-philosophicus, transl. D.F. Pears \& B.F. McGuiness, Routledge \& Kegan Paul, London.

Woodward, J. \& Pattison, S. (eds.), 2000, The Blackwell reader in pastoral and practical theology, Blackwell Publishing, Malden, MA 